\title{
Collagen Alpha-1(III) Chain
}

National Cancer Institute

\section{Source}

National Cancer Institute. Collagen Alpha-1(III) Chain. NCI Thesaurus. Code C143055.

Collagen alpha-1(III) chain (1466 aa, $139 \mathrm{kDa}$ ) is encoded by the human COL3A1 gene.

This protein plays a role in connective tissue organization. 